\title{
EVALUATION OF ANTIPROLIFERATIVE ACTIVITY OF SIDDHA ANTI-PSORIATIC FORMULATION PANCHAMUGA CHENDHURAM USING CULTURED HUMAN KERATINOCYTE CELL LINES
}

\author{
RAJALAKSHMI $\mathbf{S}^{1 *}$, RAMYA VT ${ }^{2}$, SAMRAJ $\mathrm{K}^{1}$ \\ ${ }^{1}$ Siddha Clinical Research Unit, Tirupati, Andhra Pradesh, India. ${ }^{2}$ Department of Biomedical Engineering, Rajalakshmi Engineering
} College, Chennai, Tamil Nadu, India. Email: dr.rajibsms23@gmail.com

Received: 14 February 2019, Revised and Accepted: 06 May 2019

ABSTRACT

Objectives: This study was aimed at scientifically evaluating the in vitro antipsoriatic activity of Siddha drug Panchamuga Chendhuram (PMC) in human keratinocyte (HacaT) cell lines.

Methods: The Siddha drug PMC tested for antipsoriatic activity on HacaT cell lines was morphologically examined by phase contrast microscopy, and the cell viability was determined by 3- (4, 5 dimethyl thiazole- 2 yl) -2.5-diphenyl tetrazolium bromide assay. About $100 \mu$ l of different concentrations $(2,6,10,20,30,40,50,60,70,80,90$, and $100 \mu \mathrm{g} / \mathrm{ml})$ of the test samples were prepared in the cell culture medium and incubated for $24 \mathrm{~h}$ and $48 \mathrm{~h}$ to determine the viable cells.

Results: The results revealed that Siddha drug PMC showed hopeful antiproliferative activity. In vitro studies showed that after $24 \mathrm{~h}$ and $48 \mathrm{~h}$ incubation, the inhibitory concentration $50\left(\mathrm{IC}_{50}\right)$ values of PMC $\left(\mathrm{IC}_{50} 20 \mu \mathrm{g} / \mathrm{ml}\right)$ were $72.08 \pm 27.56 \mu \mathrm{g} / \mathrm{ml}$ and $43.91 \pm 17.71 \mu \mathrm{g} / \mathrm{ml}$, respectively, as compared with Asiaticoside as a positive control with an $\mathrm{IC}_{50}$ value of $20.13 \mu \mathrm{g} / \mathrm{ml}$.

Conclusion: Thus, this study provides scientific evidence about the efficacy of the Siddha drug PMC against the HacaT cell lines confirming its traditional use in psoriasis treatment and also emphasizes the need for antipsoriatic evaluation in animal models.

Keywords: Siddha drug, Psoriasis, Chendhuram, Human keratinocyte, Antiproliferation.

(C) 2019 The Authors. Published by Innovare Academic Sciences Pvt Ltd. This is an open access article under the CC BY license (http://creativecommons. org/licenses/by/4. 0/) DOI: http://dx.doi.org/10.22159/ajpcr.2019.v12i6.32594

\section{INTRODUCTION}

Psoriasis is a serious global problem for many decades. Its prevalence rate ranges from $0.44 \%$ to $2.8 \%$ of the Indian population [1]. The name psoriasis was given by the Viennese dermatologist Von Hebra. The name is derived from the Greek word psora which means to itch [2]. Psoriasis is defined on a clinical basis as chronic, relapsing, remitting papulosquamous eruption with typical localization on the extensor surfaces such as elbows and knees involving scalp, genitalia or nails, and other sites [3]. Among the psoriasis patients, the ratio of male to female was 1.1:1. Among the affected patients, $12.5 \%$ had a family history of psoriasis [4]. Early onset disease that affects patients at age $<40$ years accounts for more than $75 \%$ of psoriasis cases [5].

Psoriasis is an autoimmune disorder. The immune system is not only the key to what causes psoriatic disease but it may also be the key to treating it, too. In 1979, the researchers discovered an accident that a drug called cyclosporine that suppresses the immune system also clears psoriasis. Since then, many effective treatments directed toward the immune system have been developed for psoriasis and psoriatic arthritis [6]. At present, the treatment of psoriasis composes of a wide range of treatment options, the prescribed synthetic drugs for the treatment of psoriasis are often associated with severe side effects; thus, researchers around the globe are searching for new, effective, and safer drugs from natural resources. Around $60-70 \%$ of the world population is using traditional medicines isolated from various medicinal plants. The herbal formulations are used not only that the herbal formulations are economical but also present lesser side effects when administered to control diseases and their secondary complications [7].
It is well known that skin diseases are cured excellently with Siddha medicines. There are lots of Siddha medicines indicated in Siddha textbooks for skin diseases. The medicines are used in two forms one as individual herbs and another as compound formulations. These are some single herbs which have potent efficacy against skin diseases proved by in vitro studies, Aristolochia bracteolata, Carum copticum, Curcuma aromatica, Indigofera aspalathoides, Nigella sativa, Smilax china, Wattakaka volubilis, Pongamia pinnata, Commiphora myrrha, Morinda tinctoria, Strychnos nux-vomica, Thespesia populnea, Cardiospermum halicacabum, Clerodendrum inerme, and Coccinia grandis. The popular Siddha compound formulations are parangipattai chooranam (Powder) parangi rasayanam, parangi pattai padhangam, kendhi mezhugu, Mahaveera Mezhugu, nandhi mezhugu, rasagandhi mezhugu, kandhaga parpam (Calx), muthuchippi parpam, sangu parpam, palagarai parpam, irunelli karpam, serangkottai nei, kandhaga sudar thailam, Siddhadhi ennai, and Garudan kilangu ennai. External oil and ointments are vetpalai thailam (oil), karappan thailam, arugan thailam, Punga thailam, Meganadha thailam, sirattai thailam, kundhriga thailam, matthan thailam, Kungiliya vennai, Amirtha vennai, Kizhinjal mezhugu, Vellai mezhugu, and Padai sangaaran [8,9]. Like single herbs the in vitro studies of compound Siddha formulations for skin diseases are still lacking; hence, the attempt is made to fill this lacuna. Panchamuga Chendhuram (PMC) is a Siddha Herbomineral formulation used in this study indicated for psoriasis in the classical Siddha textbook Pulippani Vaidhyam - 500 [10]. In this study, cultured cell line (spontaneously transformed and immortalized human keratinocyte [HacaT] cell line) was used which is commonly employed as an in vitro test model for the antiproliferative activity of new treatment due to its highly preserved differentiation capacity [11]. 


\section{METHODS}

\section{Preparation of PMC [10]}

Raw drugs were purchased from Raw drug shop, R. N. Rajan and co., Parry's, Chennai. Authentication was made by Pharmacognosy, Siddha Central Research Institute, Chennai, and purification was made as per the Siddha classical literature [12].

\section{Ingredients}

Purified rasam (Hydragyrum), purified Gandhagam (Sulfur), purified Thalagam (Arsenic trisulfide), purified Lingam (Mercury II sulfide), purified Veeram (Mercuric chloride) each $100 \mathrm{~g}$, and piper betel leaf juice Q.S.

\section{Procedure}

All the ingredients were ground well for 1 day and made into pellets (villais). The pellets were allowed to dry, and then it was ignited for small flame (Deepaagni) - $6 \mathrm{~h}$, moderate flame (Kamalaagni) - $6 \mathrm{~h}$, and high flame (Kaadaagni) - $9 \mathrm{~h}$. After self-cooling, the product was again subjected to grinding for 1 day. The final product PMC was weighed and stored in an airtight container.

\section{In vitro antiproliferative activity on HacaT cell lines $[13,14]$}

\section{Cell culture}

In vitro antipsoriatic activity was carried out on HacaT cell lines. HacaT cell lines were obtained from NCCS, Pune, India, and the procedure was carried out in Tamil Nadu Veterinary and Animal Sciences University (TANUVAS), Chennai. The cells were seeded at a concentration of $1.0 \times 105$ cells $/ \mathrm{ml}$ in a 96 well microtiter plate and grown in Dulbecco's modified eagle's medium (DMEM, Gibco) supplemented with $10 \%$ fetal bovine serum (BioWest). After $24 \mathrm{~h}$, the supernatant was decanted and therefore the monolayer was washed once. Then, $100 \mu \mathrm{l}$ of a test

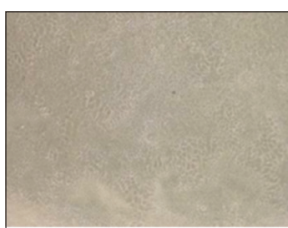

$2 \mu \mathrm{g} / \mathrm{ml}$

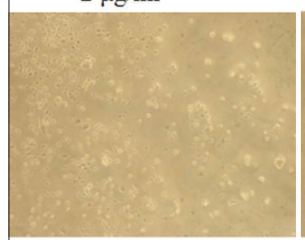

$30 \mu \mathrm{g} / \mathrm{ml}$

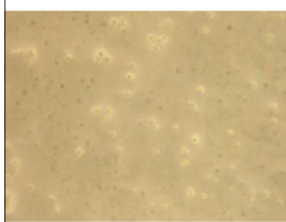

$60 \mu \mathrm{g} / \mathrm{ml}$

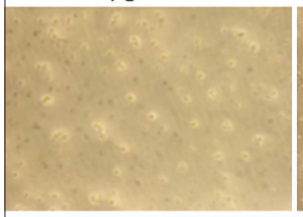

$90 \mu \mathrm{g} / \mathrm{ml}$

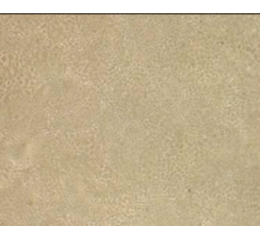

$10 \mu \mathrm{g} / \mathrm{ml}$

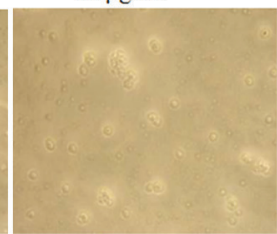

$40 \mu \mathrm{g} / \mathrm{ml}$

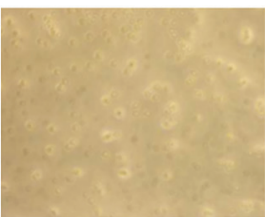

$70 \mu \mathrm{g} / \mathrm{ml}$

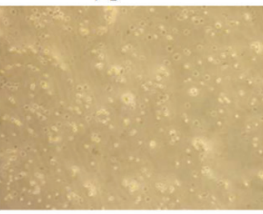

$100 \mu \mathrm{g} / \mathrm{ml}$

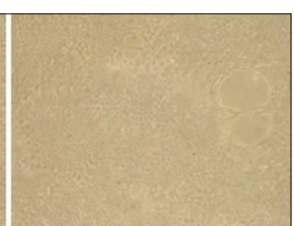

$20 \mu \mathrm{g} / \mathrm{ml}$

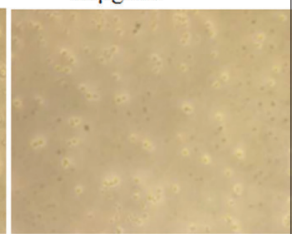

$50 \mu \mathrm{g} / \mathrm{ml}$

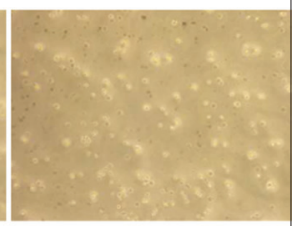

$80 \mu \mathrm{g} / \mathrm{ml}$

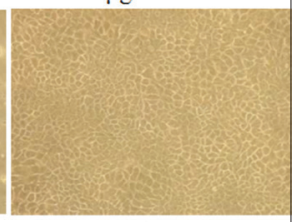

Control $\times 20$
Fig. 1: Panchamuga Chendhuram induced changes in morphology and number of human keratinocyte (HacaT) cells changes shown by phase contrast microscopy. As the concentration increased, the number of HacaT cells gradually decreased, morphological changes occurred substance in various concentrations was added to the cells in microtiter plates. Test compounds were prepared in dimethyl sulfoxide (DMSO) and then diluted with DMEM; the final concentration of DMSO was $0.2 \%$ in the culture medium. Each sample concentration was tested in triplicates. The plates were then incubated at $370^{\circ} \mathrm{C}$ for 3 days in $5 \% \mathrm{CO}_{2}$ atmosphere.

\section{Antiproliferative assay}

The antiproliferative activity was assessed by performing the $3-(4,5$ dimethyl thiazole-2 yl) -2.5-diphenyl tetrazolium bromide (MTT) assay. The ability of the cells to survive a toxic insult has been the basis of most cytotoxicity assays. This assay is based on the assumption that dead cells or their products do not reduce tetrazolium. The assay depends both on the number of cells present and on the mitochondrial activity per cell. The cleavage of MTT to a blue formazan derivative by living cells is clearly a very effective of principle on which the assay is based. The principle involved is the cleavage of tetrazolium salt MTT into a blue colored product (formazan) by mitochondrial enzyme succinate dehydrogenase. The number of cells was found to be proportional to the extent of formazan production by the cells used [15].

Cells were fixed by adding $25 \mu \mathrm{l}$ of ice-cold $50 \%$ trichloroacetic acid on top of the growth medium, and the plates were incubated at $40^{\circ} \mathrm{C}$ for $1 \mathrm{~h}$ after that plates were washed to get rid of traces of medium, drug, and serum. MTT reagent (10 $\mu \mathrm{l} ; 0.4 \%$ in $1 \%$ acetic acid) (Sigma) was added to each well and left in contact with the cells for $30 \mathrm{~min}$ after which they were washed with $1 \%$ acetic acid, rinsing 4 times until only dye adhering to the cells was left. The plates were then dried and 100 $\mu \mathrm{l}$ of $10 \mathrm{~mm}$ Tris buffer (Sigma) added to every well to solubilize the dye. The plates were shaken gently for $5 \mathrm{~min}$ and absorbance was read at $550 \mathrm{~nm}$ using a microplate reader. The readings were taken at two different incubation time ( $24 \mathrm{~h}$ and $48 \mathrm{~h}$ ). In this study, no positive control was used, but as the data available previously the results were compared to Asiaticoside. Asiaticoside is a major chemical constituent present in the plant Centella asiatica. The percentage inhibition was calculated from this data using the following formula [16]:

$$
\% \text { viability }=\frac{(\text { control })-\text { Mean OD of treated cells }}{\text { Mean OD of untreated cells }(\text { control })} \times 100
$$

Table 1: $\mathrm{IC}_{50}$ of PMC in HacaT cell lines at $24 \mathrm{~h}$ and $48 \mathrm{~h}$

\begin{tabular}{lll}
\hline Concentration $(\boldsymbol{\mu g})$ & $\begin{array}{l}\text { \% of cell inhibition } \\
\text { in } \mathbf{2 4} \mathbf{~ h}\end{array}$ & $\begin{array}{l}\text { \% of cell inhibition } \\
\text { in } \mathbf{4 8} \mathbf{~ h}\end{array}$ \\
\hline 2 & 19 & 27 \\
6 & 27 & 25 \\
10 & 35 & 30 \\
20 & 92 & 23 \\
30 & 93 & 28 \\
40 & 87 & 38 \\
50 & 89 & 48 \\
60 & 84 & 67 \\
70 & 85 & 69 \\
80 & 86 & 68 \\
90 & 85 & 52 \\
100 & 83 & 52 \\
\hline
\end{tabular}

HacaT: Human Keratinocyte cell lines, $\mathrm{IC}_{50}$ : Inhibitory concentration, PMC: Panchamuga Chendhuram

Table 2: $\mathrm{IC}_{50}$ of PMC in HacaT cell lines at $24 \mathrm{~h}$ and $48 \mathrm{~h}$

\begin{tabular}{lll}
\hline Cell line & PMC \\
\cline { 2 - 3 } & $\mathbf{2 4 ~ h ~ I C} \mathbf{5 0}_{\mathbf{0}}(\mathbf{2 0} \boldsymbol{\mu g})$ & $\mathbf{4 8 ~ h ~ I C}(\mathbf{6 0} \boldsymbol{\mu g})$ \\
\hline HacaT & $72.08 \pm 27.56^{*}$ & $43.91 \pm 17.71$
\end{tabular}

Effect of PMC on HacaT at $24 \mathrm{~h}$ shows significant inhibitory concentration, $\mathrm{IC}_{50}(24 \mathrm{~h})=72.08 \pm 27.56^{*}(\mathrm{p}<0.05)$. PMC: Panchamuga Chendhuram, HacaT: Human Keratinocyte cell lines, $\mathrm{IC}_{50}$ : Inhibitory concentration 
Table 3: MTT assay 24 h PMC

\begin{tabular}{lllllllllllll}
\hline $\begin{array}{l}\text { Concentration } \\
(\boldsymbol{\mu g})\end{array}$ & $\mathbf{1}$ & $\mathbf{2}$ & $\mathbf{3}$ & $\mathbf{4}$ & $\mathbf{5}$ & $\mathbf{6}$ & $\mathbf{7}$ & $\mathbf{8}$ & $\mathbf{9}$ & $\mathbf{1 0}$ & $\mathbf{1 1}$ & $\mathbf{1 2}$ \\
\hline $\mathrm{A}$ & 3.096 & 3.598 & 3.013 & 0.22 & 0.234 & 0.931 & 0.387 & 0.6 & 0.56 & 0.79 & 0.661 & 0.628 \\
$\mathrm{~B}$ & 3.047 & 2.407 & 2.397 & 0.226 & 0.144 & 0.461 & 0.302 & 0.649 & 0.432 & 0.487 & 0.541 & 0.78 \\
$\mathrm{C}$ & 2.828 & 2.736 & 2.435 & 0.293 & 0.159 & 1.005 & 0.307 & 0.582 & 0.554 & 0.522 & 0.392 & 0.562 \\
$\mathrm{D}$ & & & & & & & & & & & \\
$\mathrm{E}$ & 2.334 & 3.133 & 2.985 & 2.587 & 3.766 & 3.066 & 3.042 & 3.007 & 2.847 & 2.706 & 2.886 & 2.775 \\
\hline
\end{tabular}

MTT: 3- (4, 5 dimethyl thiazole-2 yl) -2.5-diphenyl tetrazolium bromide, PMC: Panchamuga Chendhuram

Table 4: MTT assay $48 \mathrm{~h}$ PMC

\begin{tabular}{|c|c|c|c|c|c|c|c|c|c|c|c|c|}
\hline $\begin{array}{l}\text { Concentration } \\
(\mu \mathrm{g})\end{array}$ & 1 & 2 & 3 & 4 & 5 & 6 & 7 & 8 & 9 & 10 & 11 & 12 \\
\hline A & 2.777 & 2.906 & 2.97 & 2.969 & 2.789 & 2.101 & 1.748 & 1.378 & 1.314 & 1.207 & 1.862 & 1.788 \\
\hline B & 2.349 & 2.965 & 2.689 & 2.966 & 3.324 & 2.545 & 2.014 & 0.853 & 0.955 & 1.438 & 1.412 & 2.041 \\
\hline $\mathrm{C}$ & 2.832 & 2.886 & 3.159 & 3.184 & 3.521 & 2.368 & 2.932 & 1.255 & 1.199 & 1.188 & 2.057 & 1.84 \\
\hline D & & & & & & & & & & & & \\
\hline E & 2.117 & 2.844 & 3.881 & 3.761 & 2.962 & Overflow & Overflow & Overflow & Overflow & 3.36 & 2.885 & 2.469 \\
\hline
\end{tabular}

A1- A12=2 $\mu \mathrm{g}, 6 \mu \mathrm{g}, 10 \mu \mathrm{g}, 20 \mu \mathrm{g}, 30 \mu \mathrm{g}, 40 \mu \mathrm{g}, 50 \mu \mathrm{g}, 60 \mu \mathrm{g}, 70 \mu \mathrm{g}, 80 \mu \mathrm{g}, 90 \mu \mathrm{g}, 100 \mu \mathrm{g}$, B1-B12=Duplicate, C1-C12=Triplicate, E1-E12=Cell control. MTT: 3- (4, 5 dimethyl thiazole- 2 yl) -2.5-diphenyl tetrazolium bromide, PMC: Panchamuga Chendhuram

\section{Statistical analysis}

The data were given as mean \pm standard deviations (SD). The statistical differences were evaluated using one-way ANOVA followed by the least significant difference as post hoc analysis (SPSS Version 19.0; SPSS Inc., Chicago, IL, USA). $\mathrm{p}=0.05$ was considered statistically significant.

\section{RESULTS}

The inhibitory concentration 50 (IC ${ }_{50}$ ) was determined as the dose that would be required to kill $50 \%$ of the cells with the respective preparation and duration. The proportion of dead cells and type of cell death after treatment was better illustrated from the morphological observations (Fig. 1). The drug PMC at $24 \mathrm{~h}$ incubation possess significant antiproliferative activity $\left(\mathrm{IC}_{50} 20 \mu \mathrm{g} / \mathrm{ml}\right.$ ) the mean and SD was $72.08 \pm 27.56 \mu \mathrm{g} / \mathrm{ml},(\mathrm{p}<0.05)$ (Tables 1 and 2$)$, whereas in $48 \mathrm{~h}$ incubation the activity decreases $\left(\mathrm{IC}_{50} 20 \mu \mathrm{g} / \mathrm{ml}\right)$ the mean and SD was $43.91 \pm 17.71 \mu \mathrm{g} / \mathrm{ml}$

\section{DISCUSSION}

Skin is the largest exposed organ of the body and is easily targeted for allergic and immunological reactions. Skin ailments, specifically dermatitis, urticaria, angioedema, psoriasis, etc., are immune-mediated disorders that are chronic, inflammatory, and proliferative in nature [17]. Psoriasis has become an important area of scientific study due to its severe effect on the quality of life, cost of treatment and toxicity, and the side effects of available medication $[18,19]$. Inhibition of hyperproliferation of epidermal keratinocytes is one of the key mechanisms by which most of the available antipsoriatic drugs act. HacaT cells are human spontaneous immortal keratinocyte cells and are often used as an effective model instead of primary-cultured keratinocytes and the data obtained from this model have shown a good correlation with in vivo skin irritation [11].

The drug PMC at $24 \mathrm{~h}$ incubation possesses significant antiproliferative activity, whereas in $48 \mathrm{~h}$ incubation the activity decreases (Tables 3 and 4). The effect of PMC at $48 \mathrm{~h}$ treatment shows only a few dead cells. In a study conducted by Khazaei et al., the cytotoxic activity of methanolic extract of bulb of Allium atroviolaceum (BAA) in MCF7, MDA-MB-231, HeLa and HepG2 cell lines, the results showed the BAA extract on $M D A-M B-231$ treated cells entered early apoptosis stage in $\mathrm{IC}_{25}, \mathrm{IC}_{50}$, and IC $\mathrm{C}_{75}$ concentrations after 24 and $48 \mathrm{~h}$. However, at $72 \mathrm{~h}$, the proportion of early apoptotic cells decreased compared to 24 and $48 \mathrm{~h}$, this suggested that the cell death might occur due to nutrient depletion in the growth media or contact inhibition [20]. In the same way, PMC at $24 \mathrm{~h}$ showed an increase in anti-proliferative activity, but after $48 \mathrm{~h}$ exposure, the activity decreases (Fig. 2) this may be due to the same

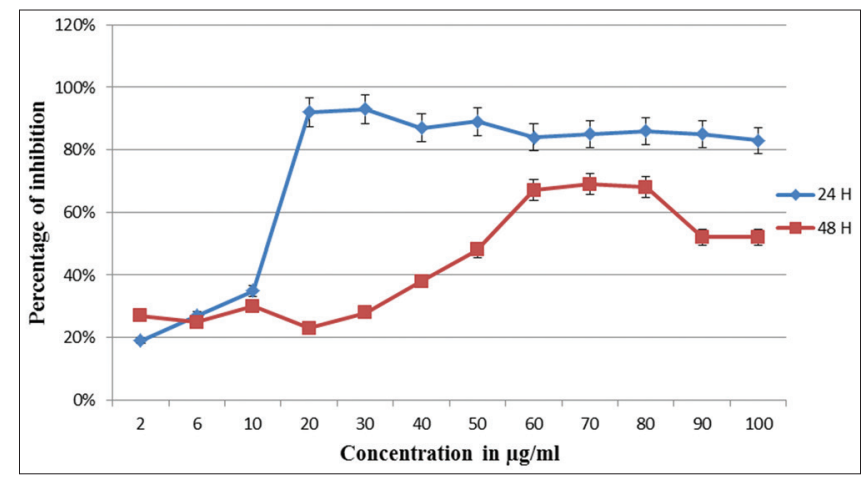

Fig. 2: In vitro antiproliferative activity of Panchamuga Chendhuram (PMC) in human keratinocyte (HacaT) cell lines.

3- (4, 5 dimethyl thiazole-2 yl) -2.5-diphenyl tetrazolium bromide assay indicated that PMC inhibited the viability of HacaT cells in a dose-dependent manner. The drug PMC at $24 \mathrm{~h}$ incubation possess significant antiproliferative activity (inhibitory concentration 50 [IC $\left.\mathrm{IC}_{50}\right] 20 \mathrm{\mu g} / \mathrm{ml}$ ) the mean and standard

deviations (SD) was $72.08 \pm 27.56 \mu \mathrm{g} / \mathrm{ml}$, whereas in $48 \mathrm{~h}$ incubation the activity decreases $\left(\mathrm{IC}_{50} 20 \mu \mathrm{g} / \mathrm{ml}\right)$ the mean SD was $43.91 \pm 17.71 \mu \mathrm{g} / \mathrm{ml}$

reason dealt in the above study. This trial drug PMC was also tested in human breast cancer (MCF-7) cell lines in that study the $\mathrm{IC}_{50}$ values are constantly increasing in 24 and $48 \mathrm{~h}$, this is contrary to the present study [21]. In the future, this study has to be carried out in animal models for a better understanding of the mechanism action of PMC. The PMC is shown $\mathrm{IC}_{50} 20 \mu \mathrm{g} / \mathrm{ml}$ in $24 \mathrm{~h}$ with good antiproliferative activity when compared with Asiaticoside as a positive control with an $\mathrm{IC}_{50}$ value of $20.13 \mu \mathrm{g} / \mathrm{ml}$.

A successful antipsoriatic drug that targets the epidermis is defined as a compound that ideally shows low toxicity and restores skin homeostasis by suppressing keratinocyte hyperproliferation, abnormal differentiation, or both [22]. The effect of PMC was observed in HacaT cell lines, and it is evident that the Siddha drug PMC has the ability to induce cell death. The probable mechanism in causing the cell death is by interacting with the cell membrane proteins and making the cell leak its cellular constituents and finally leading death, or maybe it is able to interact with the DNA or cell signaling pathways and manipulating the cellular pathways leading or triggering the cell death pathways [23]. To know the exact mechanism of Siddha drug 
PMC, the evaluation of antiproliferative activity in an animal model is a must.

\section{CONCLUSION}

This study reveals the promising skin keratinocytes antiproliferative activity of Siddha drug PMC. Hence, the hypothesis that PMC can potentially be used in antipsoriatic therapy is shown. Further works on Siddha drug PMC need to be carried out in the treatment of psoriasis.

\section{ACKNOWLEDGMENT}

The author wishes to thank Prof. Parthiban, Department of Animal Biotechnology, TANUVAS, Chennai, gave support to conduct the study.

\section{AUTHORS' CONTRIBUTIONS}

The authors have contributed equally to this work.

\section{CONFLICTS OF INTEREST}

No conflicts of interest.

\section{REFERENCES}

1. Dogra S, Yadav S. Psoriasis in India: Prevalence and pattern. Indian J Dermatol Venereol Leprol 2010;76:595-601.

2. Glickman FS. Lepra, psora, psoriasis. J Am Acad Dermatol 1986;14:863-6.

3. Rajan AK, Jeyamani SV, Kaviya U, Indumathi S, Divya R. Case study on beta blockers induced psoriasis. Int J Pharm Pharm Sci 2019;11:112-5.

4. Kumar S, Nayak CS, Padhi T, Rao G, Rao A, Sharma VK, et al. Epidemiological pattern of psoriasis, vitiligo and atopic dermatitis in India: Hospital-based point prevalence. Indian Dermatol Online J 2014;5:S6-8

5. Soliman GM, Osman SK, Hamdan AM. Preparation and evaluation of anthralin biodegradable nanoparticles as a potential delivery system for the treatment of psoriasis. Int J Pharm Pharm Sci 2015;17:36-40.

6. NPF. The Immune System and Psoriatic Diseases. Portland: National Psoriasis Foundation; 2018.

7. Zahir HZ, Kumaresa S. GC-MS analysis and antibacterial evaluation of Acalypha indica. Asian J Plant Sci Res 2013;6:46-9.

8. Walter TM, Priya TS, Paargavi AS, Devi NP, Thanalakshmi S. A review Of herbs to treat skin disorders in traditional siddha medicine. Res Rev 2014;2:7-14.
9. Muthaliar M. Siddha Materia Medica (Vegetable section). Vol. 1. Chennai: Tamilnadu Siddha Medical Council; 1988

10. Raja Mudhaliyar V, Vellaka P. Pulippani Vaidyam-500. Chennai: Rathnanaicker and Sons; 2009.

11. Tse WP, Che CT, Liu K, Lin ZX. Evaluation of the anti-proliferative properties of selected psoriasis-treating Chinese medicines on cultured HaCaT cells. J Ethnopharmacol 2006;108:133-41.

12. Thiyagarajan R. Gunapaadam Dhadhu Seeva Vaguppu. Chennai: The Tamil Nadu Siddha Medical Council; 2009.

13. Vijayalakshmi A, Ravichandiran V, Malarkodi V, Nirmala S, Jayakumari S. Screening of flavonoid "quercetin" from the rhizome of Smilax china Linn. For anti-psoriatic activity. Asian Pac J Trop Biomed 2012;2:269-75.

14. Saelee C, Thongrakard V, Tencomnao T. Effects of thai medicinal herb extracts with anti-psoriatic activity on the expression on NF- $\kappa \mathrm{B}$ signaling biomarkers in HaCaT keratinocytes. Molecules 2011;16:3908-32.

15. Alex R, Ilango K. In vitro cytotoxic activity of isolated compounds from viburnum punctatum buch-ham ex d. Don. Int J Curr Pharm Res 2017;9:85-7.

16. Athmakur H, Kondapi AK. Carmustine loaded lactoferrin nanoparticles demonstrates an enhanced antiproliferative activity against glioblastoma. Int J Appl Pharm In Vitro 2018;10:234-41.

17. Meeuwis KA, de Hullu JA, Massuger LF, van de Kerkhof PC, van Rossum MM. Genital psoriasis: A systematic literature review on this hidden skin disease. Acta Derm Venereol 2011;91:5-11.

18. Krueger G, Koo J, Lebwohl M, Menter A, Stern RS, Rolstad T, et al. The impact of psoriasis on quality of life: Results of a 1998 national psoriasis foundation patient-membership survey. Arch Dermatol 2001;137:280-4

19. De Korte J, Sprangers MA, Mombers FM, Bos JD. Quality of life in patients with psoriasis: A systematic literature review. J Investig Dermatol Symp Proc 2004;9:140-7

20. Khazaei S, Esa NM, Ramachandran V, Hamid RA, Pandurangan AK, Etemad A, et al. In vitro antiproliferative and apoptosis inducing effect of Allium atroviolaceum bulb extract on breast, cervical, and liver cancer cells. Front Pharmacol 2017;8:5

21. Rajalakshmi S, Musthafa MM, Isai M, Sathiyarajeswaran $P$. A comparative study to evaluate the anti-cancer activity of siddha drugs "veera rasa padhangam" and "panchamuga chendhuram" with the standard drug taxol. Int J Curr Res Chem Pharm Sci 2017;4:29-33.

22. Pol A, Bergers M, Schalkwijk J. Comparison of antiproliferative effects of experimental and established antipsoriatic drugs on human keratinocytes, using a simple 96-well-plate assay. In Vitro Cell Dev Biol Anim 2003;39:36-42.

23. Banala RR, Vemuri SK, Reddy AV, Subbaiah GP. Aqueous extract of Acalypha indica leaves for the treatment of psoriasis: In-vitro studies. Int J Bioassays 2017;6:5360-4 